6. Стилістичні фігури у мові літературного твору. URL: https://studfile.net/preview/7163442/page:8/ (дата звернення: 27.01.2021)

7. Kirimli M. Yusuf ile Züleyha / Mahmud Kirimli, neşirge azirlayan I.H. Ertaylan; İstanbul Üniversitesi Edebiyat Fakültesi yainları. - № 860. İstanbul, 1960. - $122 \mathrm{~s}$.

DOI https://doi.org/10.30525/978-9934-26-039-1-41

\title{
LABELING TACTICS AS A LINGUISTIC MARKER OF DONALD TRUMP'S CONCEPTUAL STYLE
}

\author{
Yenikeyev D. S. \\ Postgraduate Student \\ Zaporizhzhia National University \\ Zaporizhzhia, Ukraine
}

Politicians and their speeches are always under the scrutiny of the public. In their speeches, politicians try to represent themselves as positively as possible and focus on the negative features of their competitors with the help of various language manipulations.

As the researchers define this phenomenon, «linguistic manipulation is a kind of manipulative influence carried out through the skillful use of certain language resources for the purpose of latent influence on the cognitive and behavioral activity of the addressee» [4, p. 25]. One such technique of linguistic manipulation is «labeling», which is aimed at using language means for «attaching» some kind of attitude towards opponents.

This technique is frequently used by Donald Trump. As a former successful media person, he is well aware of what this action is capable of. The technique of sticking labels is «the use of negative words in order to discredit ideas, plans of the individual, to cause a feeling of prejudice, fear, hatred, without resorting to an objective assessment or analysis» [1, p. 42]. Therefore, we can see that labels are subjective statements, and their purpose is to highlight negative features of a person.

The former US president is famous for his great love for the social network Twitter. In his tweets, he was not shy about naming and describing opponents. Negative nomination is a "publicistic label that «condenses» in itself a negative emotional charge, which has a powerful effect on the reader's 
perception» [3, p. 105]. The keyword here is «emotional», as emotionality and expressiveness are main features of Donald Trump's idiostyle.

Repeatedly in his speeches, Trump called Joe Biden, his rival in the presidential race, Crazy Joe Biden and Sleepy Joe. In these statements, Donald Trump drew people's attention to the fact that Biden is a bad candidate for the President of the United States because he must be an energetic person with a sound mind: Crazy Joe Biden is trying to act like a tough guy. Actually, he is weak, both mentally and physically, and yet he threatens me, for the second time, with physical assault. He doesn't know me, but he would go down fast and hard, crying all the way. Don't threaten people Joe! [2] In this example we can see such linguistic markers of negative labeling as words with pejorative connotation: crazy, mentally and physically weak. Apart from that, such linguistic units as threaten and physical assault imply additional negative characteristic of being dangerous.

The following statement shows the implications of the nickname Sleepy: Sleepy Joe has been in politics for 40 years, and did nothing. Now he pretends to have the answers. He doesn't even know the questions. Weakness will never beat anarchists, looters or thugs, and Joe has been politically weak all of his life. LAW \& ORDER! [2] In this case sleepy means not active enough to be an efficient politician.

Such political opponents of Trump in the 2020 presidential race as Michael Bloomberg and Bernie Sanders were not left without nicknames. The former mayor of New York was referred to by Trump as Mini Mike. The reason for this nickname was his height, which is 173 centimeters.

Bernie Sanders is known to Trump supporters as Crazy Bernie. The nickname was based on Bernie Sanders' unusual behavior during his public appearances: Looks like Crazy Bernie is doing well in the Great State of Nevada. Biden \& the rest look weak, \& no way Mini Mike can restart his campaign after the worst debate performance in the history of Presidential Debates. Congratulations Bernie, \& don't let them take it away from you! [2]

We can observe usage of these nicknames quite frequently: Crazy, chaotic Democrat Debate last night. Fake News said Biden did well, even though he said half of our population was shot to death. Would be OVER for most. Mini Mike was weak and unsteady, but helped greatly by his many commercials (which are not supposed to be allowed) [2]. Apart from referring to the opponent's height, mini also implies weak and unsteady.

Another invention of Donald Trump was the nickname for Senator and presidential candidate Elizabeth Warren. Trump began calling her Pocahontas in reference to her claims that she is a descendant of the Indians who inhabited the United States before the arrival of the first colonists. As it turned out later, 
all these statements were far from the truth: Seriously failed presidential candidate, Senator Elizabeth «Pocahontas» Warren, just introduced an Amendment on the renaming of many of our legendary Military Bases from which we trained to WIN two World Wars. Hopefully our great Republican Senators won't fall for this! [2] In this case, the nickname helped to remind people of the false claims of the opponent.

There are many who do not feel sympathy for Trump. Among such people is the Speaker of the House of Representatives, Nancy Pelosi. In her appearance, she is distinguished by a dislike for the 45th President of the United States. Due to a number of actions and statements, Trump gave her the nickname Crazy Nancy Pelosi: Crazy Nancy Pelosi deleted this from her Twitter account. She wanted everyone to pack into Chinatown long after I closed the BORDER TO CHINA. Based on her statement, she is responsible for many deaths. She's an incompetent, third-rate politician! [2] During the pandemic, Donald Trump considered her words against the implemented restrictions as irresponsible.

Trump sometimes uses the labeling technique for the people he has worked with. A similar example is John Bolton, who served as the president's national security adviser. Bolton was distinguished by excessive rigidity in making decisions important for the country. That is why Trump began to call him $M r$. Tough Guy: And you know John wasn't in line with what we were doing. And, actually, in some cases he thought it was too tough, what we were doing. Mr. Tough Guy [5].

Thus, it can be concluded that the labeling technique is effective in matters of negative presentation of one's opponents. Comparing with other kinds of negative statements, labels might be more emotionally colored and appealing to the audience. The perspective of our further research is the analysis of other particular features of American political leaders' speeches.

\section{References:}

1. Bulgakova N. Verbal labels as a lexico-semantic and linguo-ecological concept. The world of the Russian word. 2012, №2. P. 42 - 47 [Electronic resource] - Access mode: https://cyberleninka.ru/article/n/slovesnye-yarlykikak-leksiko-semanticheskoe-i-lingvoekologicheskoe-ponyatie/viewer

2. Donald Trump's Twitter [Electronic resource] - Access mode: https://twitter.com/realDonaldTrump

3. Klushina N. Stylistics of publicistic text. Moscow, 2008. P. 105-106 [Electronic resource] - Access mode: https://cyberleninka.ru/article/n/ klushina-n-i-stilistika-publitsisticheskogo-teksta-m-2008/viewer 
4. Kopnina G. Speech manipulation. $6^{\text {th }}$ edition. Moscow : FLINTA, 2017. $170 \mathrm{p}$.

5. Latest Politics News [Electronic resource] - Access Mode: https://www.aol.com/?err=404\&err_url=https $\% 3 \mathrm{a} \% 2 \mathrm{f} \% 2 \mathrm{fwww}$. aol.com $\% 2 \mathrm{far}$ ticle $\% 2$ fnews $\% 2 \mathrm{f} 2019 \% 2 \mathrm{f} 09 \% 2 \mathrm{f} 11 \% 2 \mathrm{ftrump}-\mathrm{mr}$-tough-guy-bolton-

DOI https://doi.org/10.30525/978-9934-26-039-1-42

\title{
COLLOCATION AS A MINIMAL UNIT OF VOCABULARY ACQUISITION BUILDING IN ENGLISH LEARNING PROCESS
}

\author{
Zhelobytska T. V. \\ Senior Lecturer at Applied Linguistics, Comparative Philology \\ and Translation Studies Department, \\ Postgraduate Student at Applied Linguistics, Comparative Philology \\ and Translation Studies Department \\ National Pedagogical Dragomanov University \\ Kyiv, Ukraine
}

It is vitally important for learners to build a large vocabulary in the English language which they are studying. Various researchers have looked into the number of word families in different texts to see how big that vocabulary might need to be. A general rule of thumb for deciding how many words learners need in order to read a text without support is $98 \%$ and with support is $95 \%$. Various kinds of texts have different vocabulary loads. Canadian linguist Nation $[14$, p. 59-82] found that $98 \%$ is reached for newspapers, novels, and university-level texts at 8,000-9,000 word families plus proper nouns. Another Associate Professor in Applied Linguistics Coxhead [4, p.34] found the same load of 8,000-9,000 plus proper nouns at $98 \%$ coverage for novels that might be read at the high school level, such as Clepto, Split by Lori Weber (Canadian English, CE), The Bell Jar by Sylvia Plath (American English, AE), Pride and Prejudice by Jane Austen (British English, BE). A study of movies by Webb $\&$ Rodgers [18, p.420], for example, found that $95 \%$ coverage was reached at 3,000 word families plus proper nouns and marginal words. The authors also found that $98 \%$ was reached at 6,000 word families plus proper nouns and marginal words. Dang and Webb [7, p. 68] looked at academic spoken English and found just over $96 \%$ coverage with 4,000 word families plus proper nouns, but $98 \%$ coverage at 8,000 word families plus proper nouns and marginal words. In another study, Coxhead and Walls [5, p. 62] developed a corpus of 